\title{
TRANSPARANSI PENGELOLAAN ALOKASI DANA DESA (ADD) DALAM PEMBANGUNAN DESA DI DESA SIMPANG BANGKUANG KECAMATAN PAKU KABUPATEN BARITO TIMUR
}

\author{
Oleh: ANDY PRIANTO
}

\begin{abstract}
ABSTRAK
Penelitian ini dilakukan di Desa Simpang Bangkuang Kecamatan Paku Kabupaten Barito Timur. Tujuan dari penelitian ini adalah untuk mengetahui dan mendeskripsikan bagaimana transparansi pengelolaan Alokasi Dana Desa (ADD) di Desa Simpang Bangkuang Kecamatan Paku Kabupaten Barito Timur. Fokus penelitian dalam penelitian terdiri dari ketersediaan pengumuman kebijakan anggaran, ketersediaan dokumen anggaran dan mudah diakses, ketersediaan laporan pertanggungjawaban yang tepat waktu dan terakomodasinya suara/usulan rakyat. Teknik pengumpulan data dilakukan dengan cara penelitian lapangan yang terdiri dari observasi, wawancara dan dokumentasi, sedangkan informan diambil secara purposive sampling dan accidental sampling. Jenis penelitian yang digunakan adalah deskriptif dan akan di analisa secara kualitatif. Hasil penelitian menujukan bahwa transparansi oleh pemerintah desa dalam pengelolaan Alokasi Dana Desa (ADD) di Desa Simpang Bangkuang Kecamatan Paku Kabupaten Barito Timur sudah terlaksana dengan baik. Hal ini dapat dilihat bagaimana pemerintah desa memenuhi transparansi mulai dari menyediakan pengumuman kebijakan anggaran desa, menyediakan dokumen anggaran dan mudah diakses oleh masyarakat, menyediakan laporan pertanggungjawaban yang tepat waktu dan mengakomodasi suara/usulan masyarakat desa.
\end{abstract}

\section{Kata kunci : transparansi, alokasi dana desa, kebijakan, pemerintah desa}

\begin{abstract}
This research was conducted in Simpang Bangkuang Vilage, Paku Subdistrict, East Barito District. This research aimed to find out and describe how the management transparancy of allocation of vilage funds (ADD) in vilage development in Simpang Bangkuang Vilage, Paku Sub-district, East Barito District. The focus of this research was finance policy announcement, budget document which was easy to access, the on time of accountability report and accomodating people's opinion. The technique of collecting the data was done by the research which included observation, interview and documentation, whereas the informants were taken by purposing sampling and accidental sampling. The type of this research was descriptive and it would analyze qualitatively. The result of the research showed that the transparency that was done by the villagegovernment in allocating of village funds (ADD) in Simpang Bangkuang Vilage, Paku Sub-
\end{abstract}


district, East Barito District was run weel. It could be seen from the way vilage government fulfill the trasparancy from providing vilage budged announcement, providing budget document that was easy to access, providing on time responsibility report and accomodating villagers' opinion.

\section{Keywords: transparancy, the vilage funds allocation, policy, village government}

\section{PENDAHULUAN}

Berdasarkan Undang- Undang (UU) Nomor 6 Tahun 2014 tentang Desa, desa telah mengalami perubahan segi regulasi secara siqnifikan yaitu tidak lagi menjadi bagian UU Nomor 32 Tahun 2004 tentang Pemerintah Daerah. Pada hakekatnya UU desa memiliki visi dan misi yang memberikan kewenangan luas kepada desa di bidang penyelenggaraan pemerintahan desa, pelaksanaan pembangunan desa, pembinaan masyarakat desa, dan pemberdayaan masyarakat desa berdasarkan prakarsa masyarakat, hak asal usul, dan adat istiadat desa. UU Desa juga memberi jaminan yang lebih pasti bahwa setiap desa akan menerima dana dari pemerintah melalui anggaran negara dan daerah yang jumlahnya berlipat jauh di atas jumlah yang selama ini tersedia dalam anggaran desa. Kebijakan ini memiliki konsekuensi dalam pengelolaanya yang seharusnya dilaksanakan secara profesional, efektif dan efisien, serta akuntabel yang didasarkan pada prinsipprinsip manajemen publik yang baik agar terhindar dari resiko terjadinya penyimpangan, penyelewengan dan korupsi sehingga perlu adanya penelitian mengenai transparansi pengelolaan Alokasi Dana Desa (ADD) dalam pembangunan desa. Pemerintah dan DPR memiliki komitmen yang kuat terkait kebijakan ini, yang dibuktikan dengan telah disetujuinya anggaran dana desa sejumlah Rp 20.7 triliun dalam APBN-P Tahun 2015 yang akan disalurkan ke 74.093 Desa diseluruh Indonesia sumber Media Indonesia. Pemerintah menargetkan agar anggaran tersebut dapat segera tersalurkan keseluruh desa.

Peneliti tertarik untuk mengadakan penelitian tentang Transparansi Pengelolaan Alokasi Dana Desa (ADD) Dalam Pembangunan Desa di Desa Simpang Bangkuang Kecamatan Paku Kabupaten Barito Timur dimana peneliti ingin mengetahui bagaimana keterbukaan informasi oleh pemerintah desa terkait pengelolaan Anggaran Dana Desa (ADD) yang diterapkan di Desa Simpang Bangkuang Kecamatan Paku Kabupaten Barito Timur. Selain itu, desa ini terpilih sebagai lokasi penelitian karena termasuk desa dengan penerimaan Anggaran Desa yang dapat dikatakan cukup besar yaitu Dana Desa (DD) Rp 595.688.000 dan Alokasi Dana Desa (ADD) Rp 285.563.571 Sumber APBdes Desa Simpang Bangkuang Tahun 2016 besarnya penganggaran dana yang disalurkan oleh Pemerintah ke Desa Simpang Bangkuang yang dimana di prioritaskan dalam Pembangunan Desa. Karena sebagian besar Anggaran Desa diperuntukan bagi masyarakat maka keterbukaan informasi terkait pengelolaan anggaran desa benarbenar harus dipertanggungjawabkan oleh pemerintah desa sehingga nantinya 
diharapkan dapat menciptakan pembangunan yang merata dan bermanfaat bagi seluruh masyarakat desa.

\section{TINJAUAN PUSTAKA Good Governance}

Secara umum good governance diartikan sebagai penyelenggaraan pemerintahan yang baik yang terkait dengan isu transparansi, akuntabilitas publik dan sebagainya. Untuk mewujudkan pemahaman good governance yang sebenarnya amatlah pelik dan kompleks, tidak hanya memperjuangkan transparansi dana akuntabilitas saja. Good governance lebih dari sekedar usaha untuk memperbaiki kepemerintahan semata akan tetapi kenyataannya jauh lebih pelik dan kompleks. Good governance menurut World Bank ialah suatu penyelenggaraan manajemen pembangunan yang solid dan bertanggungjawab yang sejalan dengan prinsip demokrasi dan pasar yang efisien, penghindaran terhadap kemungkinan salah alokasi dan investasi, dan pencegahan korupsi baik secara politik maupun administratif, menjalankan disiplin anggaran serta penciptaan legal dan political framework bagi tumbuhnya aktivitas usaha.

\section{Transparansi}

Salah satu aktualisasi nilai dan prinsip-prinsip good governance adalah Transparansi. Aparatur dan sistem manajemen publik harus mengembangkan keterbukaan dan sistem akuntabilitas. Bersikap terbuka dan bertanggungjawab untuk mendorong para pimpinan dan seluruh sumber daya manusia di dalamnya berperan dalam mengamalkan dan melembagakan kode etik sehingga dapat menjadikan diri mereka sebagi panutan masyarakat, dan itu dilakukan sebagai bagian dari pelaksanaan tanggung jawab dan pertanggungjawaban kepada masyarakat dan negara.Transparansi adalah keterbukaan pemerintahan dalam membuat kebijakan-kebijakan, sehingga dapat diketahui dan diawasi oleh DPR dan masyarakat. Transparansi pada akhirnya akan menciptakan horizontal accountabilility antara pemerintah dengan masyarakat. Ini akan menciptakan pemerintahan yang bersih, efektif, efisien, akuntabel, dan responsive terhadap aspirasi dan kepentingan masyarakat. Transparansi tidak hanya penting dalam penyelenggaraan pemerintahan tetapi juga dalam penyelenggaraan pelayanan pubik.

\section{Indikator Transparansi}

Pemerintah yang baik akan transparan terhadap rakyat baik tingkat pusat maupun daerah dan harus dibangun dalam rangka kebebesan aliran informasi yang tersedia harus memadai dan dapat dimengerti, seperti yang dikemukakan oleh Dwiyanto (2007), mengatakan transparansi dibangun di atas dasar arus informasi yang bebas, seluruh proses pemerintahan, lembaga-lembaga dan informasi perlu diakses oleh pihak-pihak yang berkepentingan, dan informasi yang tersedia harus memadai agar dapat dimengerti dan dipantau. Tidak jauh berbeda dengan pendapat yang dikemukakan oleh Dwiyanto (2005), transparan adalah informasi yang 
relevan yang tersedia untuk manfaat publik secara umum dalam hal ini peraturan dan keputusan pemerintah tersedia secara jelas dan disebarkan.

Dwiyanto (2000), mengungkapkan keuntungan dari adanya transparansi ialah:

1. Transparansi dapat mengurangi ketidakpastian yang memberikan kontribusi pada stabilitas fiskal dan makroekonomi sehingga penyesuaian-penyesuaian dikemudian hari dapat diminimalisir.

2. Meningkatkan akuntabilitas pemerintah, legislatif, media dan masyarakat dapat melaksanakan fungsi kontrol terhadap pemerintah lebih baik jika mereka mempunyai informasi tentang kebijakan, pelaksanaan kebijakan dan penerimaan atau pengeluaran pemerintah. Para pejabat publik akan berlaku lebih bertanggungjawab jika keputusan yang diambil dilakukan secara terbuka/transparan untuk publik dan dapat mencegah adanya korupsi, kolusi dan nepotisme.

3. Transparansi dapat mengingkatkan kepercayaan kepada pemerintah dan membangun hubungan sosial yang lebih erat, misalnya masyarakat dapat memahami kebijakan pemerintah dan bahkan mendukung kebijakan tersebut.

4. Mengingkatkan iklim investasi. Pemahaman yang jelas terhadap kebijakan dan tindakan pemerintah akan mengundang investor baik dalam maupun luar negeri untuk berinvestasi lebih banyak.

Kriteria transparansi anggaran yang dapat digunakan untuk mengukur transparansi dalam perencanaan dan penganggaran seperti yang dikemukakan oleh Kristianten (2006), bahwa transparansi dapat diukur melalui beberapa indikator:

1. Ketersediaan dan aksesibilitas dokumen anggaran.

2. Kejelasan dan kelengkapan informasi dalam dokumen anggaran.

3. Keterbukaan proses.

4. Kerangka regulasi yang menjamin transparansi.

Mardiasmo (2003), juga mengemukakan bahwa anggaran yang disusun oleh pihak eksekutif dikatakan transparansi jika memenuhi beberapa kriteria berikut:

1. Terdapat pengumuman kebijakan anggaran.

2. Tersedia dokumen anggaran dan mudah diakses.

3. Tersedia laporan pertanggungjawaban yang tepat waktu.

4. Terakomodasinya suara/usulan rakyat.

5. Terdapat sistem pemberian informasi kepada publik.

\section{Pengelolaan Alokasi Dana Desa (ADD)}

Kata pengelolaan dapat disamakan dengan manajemen, yang berarti pengaturan atau pengurusan (Adisasmita, 2011: 31). Pengelolaan diartikan sebagai suatu rangkaian pekerjaan atau suatu usaha yang dilakukan oleh sekelompok orang untuk melakukan serangkaian kerja dalam mencapai tujuan tertentu. Manajemen diartikan sebagai proses merencanakan, mengorganising, memimpin, dan mengendalikan upaya organisasi dengan segala aspeknya agar tujuan organisasi tercapai secara efektif dan efisien. Oleh karena itu, apabila dalam sistem dan proses perencanaan, pengorganisasian, pengarahan, penganggaran dan sistem pengawasan 
tidak baik, proses manajemen secara keseluruhan tidak lancar sehingga proses pencapaian tujuan akan terganggu atau mengalami kegagalan.

\section{Perencanaan Alokasi Dana Desa}

Perencanaan dana desa berkaitan dengan perencanaan pembangunan desa yang mengacu pada konsep membangun desa. Konsep membangun desa dalam konteks perencanaan adalah bahwa dalam merencanakan pembangunan, desa perlu mengacu pada perencanaan pembangunan Kabupaten/Kota. Hal tersebut sebagaimana telah diatur dalam UU No.6 Tahun 2014 terutama pada pasal 79 dan pasal 80. Perencanaan Desa disusun secara berjangka meliputi:

1. Rencana pembangunan jangka menengah desa (RPJMDes) untuk jangka waktu 6 (enam) tahun, dan

2. Rencana pembangunan tahunan desa atau yang disebut rencana kerja pemerintah desa (RKPDes), merupakan penjabaran dari rencana pembangunan jangka menengah desa untuk jangka waktu 1 (satu) tahun.

\section{Pertanggungjawaban/ Evaluasi Alokasi Dana Desa}

Kepala desa adalah penanggungjawab dari pengelolaan keuangan desa secara keseluruhan. Dalam PP. 43 tahun 2014 pasal 03-104 mengatur tata cara pelaporan yang wajib dilakukan oleh kepala desa. Kepala desa diwajibkan menyampaikan laporan realisasi pelaksanaan APBD desa kepada bupati/walikota setiap semester tahun berjalan (laporan semester). Selain itu, Kepala desa juga diwajibkan menyampaikan laporan pertanggungjawaban realisasi pelaksanaan APBD desa kepada bupati /walikota setiap akhir tahun anggaran (laporan tahunan). Laporan yang dibuat oleh kepala desa ditunjukkan kepada Bupati/Walikota yang disampaikan melalui camat. Dari PP No. 43 Tahun 2014 dan permendagri No.113 Tahun 2014 terlihat bahwa laporan pertanggungjawaban yang harus dibuat oleh kepala desa harus terintegrasi secara utuh, tidak melihat sumber dana yang diperoleh desa. Laporan pertanggungjawaban penggunaan APBD desa secara keseluruhan termasuk dalam salah satu sumber dana yang masuk dalam APBD desa. Selanjutnya dijelaskan pengaturan pelaporan dan pertanggungjawaban penggunaan APBD desa tercantum dalam permendagri No. 113 Tahun 2014 tentang pengelolaan keuangan desa. Dalam Permendagri tersebut, diatur pula standar format pelaporan pertanggungjawaban yang harus disusun oleh kepala desa.

\section{Pembangunan Desa}

Secara umum ada suatu kesepakatan bahwa pembangunan merupakan proses untuk melakukan perubahan Siagian (1983): dalam bukunya Admnistrasi Pembangunan mengemukakan pembangunan adalah sebagai suatu perubahan, mewujudkan suatu kondisi bernegara dan bermasyarakat yang lebih baik dari kondisi sekarang, sedangkan pembangunan sebagai suatu pertumbuhan menunjukkan kemampuan suatu kelompok untuk terus berkembang, baik secara kualitatif maupun kuantitatif dan merupakan sesuatu yang mutlak harus terjadi dalam pembangunan. Pembangunan masyarakat desa (pedesaan) adalah seluruh 
kegiatan pembangunan yang berlangsung di desa dan meliputi seluruh aspek kehidupan masyarakat, serta dilaksanakan secara terpadu dengan mengembangkan swadaya gotong royong. Tujuannya adalah untuk meningkatkan kesejahteraan masyarakat damai, demokratis, berdaya saing, maju dan sejahtera. Pada hakekatnya tujuan dari pembangunan pedesaan adalah mengingkatkan keulitas hidup masyarakat pedesaan melalui pencapaian kemajuan sosial ekonomi secara berkeseimbangan dengan tetap memperhatikan persamaan hak dan menjunjung tinggi prinsip-prinsip keadilan bagi masyarakat secara keseluruhan. Pembangunan dilaksanskan harus sesuai dengan masalah yang dihadapi, potensi yang dimiliki, aspirasi masyarakat dan prioritas pembangunan desa itu sendiri yang telah ditetapkan. Pembangunan pedesaan ini mempunyai ruang lingkup yang sangat luas dan memiliki sasaran umum, tetapi dapat dikelompokkan sebagai berikut :

1. Tersedianya infrakstruktur fisik dan sosial yang mencakup jaringan jalan fasilitas pendidikan dan kesehatan yang tersebar diseluruh wilayah, Pembangunan sarana dan prasarana pedesaan (meliputi pengairan dan lingkungan pemukinan).

2. Pemberdayaan masyarakat ;Peningkatan kempuan sumberdaya manusia (SDM) dan pengelolaan sumberdaya alam ( SDA).

\section{METODE PENELITIAN Jenis Penelitian}

Untuk menemukan, memahami, dan mendapatkan deskripsi secara jelas serta mendalam tentang permasalah yang akan diteliti, maka dalam penelitian ini peneliti menggunakan penelitian kualitatif. Sesuai dengan jenis penelitian ini, maka penelitian kualitatif adalah sebagai prosedur penelitian yang menghasilkan data deskriftif berupa kata-kata terlulis atau lisan dari orang-orang dan perilaku yang dapat diamati dan kemudahan dinyatakan dalam bentuk kata-kata, kalimat maupun gambar. Untuk itu sangatlah diperlukan pengamatan dan pencarian informasi secara mendalam dalam penelitian ini. Dengan memberikan gambaran melakukan analisis terutama berhubungan dengan Transparansi pengelolaan Alokasi Dana Desa (ADD) dalam pembangunan Desa di Desa Simpang Bangkuang Kecamatan Paku Kabupaten Barito Timur, peneliti menggunakan jenis penelitian kualitatif.

\section{Lokasi Penelitian}

Lokasi penelitian merupakan tempat atau wilayah dimana penelitian dilaksanakan. Lokasi yang di ambil dalam penelitian adalah Desa Simpang Bangkuang Kecamatan Paku Kabupaten Barito Timur. Adapun alasan alasan dipilihnya lokasi tersebut didasarkan beberapa pertimbangan (1) Desa Simpang Bangkuang merupakan desa jumlah penduduk dapat dikatakan cukup banyak di Kecamatan Paku yaitu 593 jiwa: (2) termasuk desa dengan penerimaan Alokasi Dana Desa yang cukup besar di Kecamatan Paku yakni Rp 285,563,571; 3) akses penelitian ke sumber data (pemerintah, masyarakat, pihak terkait lainya) khususnya yang terkait 
secara langsung maupun tidak langsung dalam pengelolaan Alokasi Dana Desa sehingga peneliti berharap tidak mengalami kendala dalam memperoleh data.

\section{Fokus Penelitian}

Untuk memudahkan peneliti dalam melakukan penelitian, maka peneliti membuat fokus penelitian. Berdasarkan rumusan masalah yang telah ditetapkan maka yang menjadi kajian dalam penelitian ini adalah sebagai berikut:

Transparansi di ukur dari:

a) Terdapat pengumuman kebijakan anggaran.

b) Tersedia dokumen anggaran dan mudah diakses.

c) Tersedia laporan pertanggungjawaban yang tepat waktu.

d) Terakomodasinya suara/usulan rakyat.

e) Faktor penghambat dan pendukung dalam pengelolaan ADD

\section{Teknik Pengumpulan Data} adalah:

Adapun teknik pengumpulan data yang dipergunakan dalam penelitian ini

\section{Pengamatan (observasi)}

Observasi adalah pengamatan secara langsung ke objek penelitian. Observasi dilakukan untuk melihat dengan jelas dan lebih dekat dengan objek yang diteliti. Berdasarkan lokasi penelitian yang telah ditetapkan maka peneliti melakukan observasi ke Desa Simpang Bangkuang. Tujuan observasi ini untuk melihat keadaan dilapangan dengan mencatat apa yang dianggap penting terkait dengan pengelolaan alokasi dana desa dalam pembangunan desa. Alat yang digunakan selama observasi adalah berupa alat perekam gambar dan suara ( audi recording), pensil, buku catatan dan lain-lain yang diperlukan.

\section{Wawancara (interview)}

Wawancara dilakukan secara terbuka dan mendalam agar dapat mengetahui hal-hal yang berkaitan dengan Transparansi pengelolaan alokasi dana desa dalam pembangunan desa. Tujuan wawancara untuk menggali informasi sedalamdalamnya terkait dengan fokus kajian penelitian. Dalam hal ini peneliti akan melakukan wawancara kepada: 1) Kepala Desa. 2) Sekretaris Desa. 3) Badan Permusyawaratan Desa. 4) Masyarakat Desa. Yang nantinya sasaran utama dalam wawancara adalah Masyarakat Desa minimal 10 orang diminta keterangan terkait pengelolaan Alokasi Dana Desa di Desa Simpang Bangkuang Kecamatan Paku Kabupaten Barito Timur.

3. Dokumentasi

Dokumentasi adalah pengumpulan bahan atau data yang berasal dari dokumentasi, litelatur tentang kajian penelitian. Dokumentasi dapat berupa dokumen, catatan, foto, Koran media local, laporan maupun rekaman yang relevan dengan fokus kajian yakni pengelolaan alokasi dana desa dalam pembangunan desa di Desa Simpang Bangkuang Kecamatan Paku Kabupatan Barito Timur. Hasil penelitian akan lebih dapat dipercaya jika didukung oleh dokumen. Untuk semakin memperkaya informasi dan data yang dibutuhkan maka peneliti memanfaatkan 
media internet sehingga data-data dan informasi yang diperoleh semakin lengkap dan mendalam, yaitu data dan informasi yang diperoleh melalui website dan situssitus yang relevan dengan rencana penelitian.

\section{HASIL PENELITIAN}

Desa Simpang Bangkuang merupakan desa yang berada diwilayah Kecamatan Paku Kabupaten Barito Timur, dengan luas $\pm 29 \mathrm{~km}^{2}$. Desa Simpang Bangkuang memiliki terdiri dari 0 Rukun Warga (RW) dan 4 Rukun Tetangga (RT). Secara administratif Desa Simpang Bangkuang batasa wilayah sebelah utara berbatasan dengan Desa Patung, sebelah timur berbatasan dengan Desa Tarinsing, sebelah selatan berbatasan dengan Desa Tampa, dan sebelah barat berbatasan dengan wilayah Desa Wuran.

\section{Jumlah Penduduk}

Jumlah penduduk Desa Simpang Bangkuang Kecamatan Paku Kabupaten Barito Timur terhitung berdasarkan data kependudukan sampai dengan bulan Desember 2016 berjumlah 593 jiwa dengan penduduk berjenis kelamin laki-laki berjumlah 280 jiwa dan penduduk berjenis kelamin perempuan yaitu 313 jiwa.

Tabel 4.1 Jumlah Penduduk Menurut Jenis Kelamin

\begin{tabular}{|l|l|}
\hline Laki -Laki & 313 Orang \\
\hline Perempuan & 280 Orang \\
\hline Jumlah Total & 593 Orang \\
\hline Jumlah Kepala Keluarga (KK) & $175 \mathrm{KK}$ \\
\hline Kepadatan penduduk & $20 \mathrm{jiwa} / \mathrm{km}$ \\
\hline
\end{tabular}

Sumber: Profil Desa Simpang Bangkuang

\section{Kondisi Ekonomi}

Mata pencaharian adalah pekerjaan atau pencaharian utama yang dikerjakan untuk kebutuhan sehari-hari. Mata pencaharian merupakan aktifitas manusia untuk memperoleh taraf hidup yang layak dimana daerah satu dengan daerah yang lainnya berbeda sesuai dengan taraf kemampuan penduduk dan keadaan demografinya. Mata pencaharian di bedakan menjadi dua yaitu mata pencaharian pokok dan mata pencaharian sampingan. Mata pencaharian pokok adalah keseluruhan kegiatan untuk memanfaatkan sumber daya yang ada. Sedangkankan mata pencaharian sampingan adalah mata pencaharian diluar mata pencaharian pokok.

Tabel 4.2 Mata Pencaharian

\begin{tabular}{|c|l|c|c|c|}
\hline \multirow{2}{*}{ NO } & \multirow{2}{*}{ Pekerjaan } & \multicolumn{2}{|c|}{ Jumlah Jiwa } & \multirow{2}{*}{ Jumlah } \\
\cline { 3 - 4 } & & Laki-laki & Perempuan & \\
\hline 1 & PNS & 9 & 9 & 18 \\
\hline 2 & Pensiunan PNS & 1 & & 1 \\
\hline
\end{tabular}




\begin{tabular}{|c|l|c|c|c|}
\hline 3 & PETANI & 233 & 252 & 485 \\
\hline 4 & MONTIR & 3 & & 3 \\
\hline 5 & $\begin{array}{l}\text { Karyawan } \\
\text { Perusaan }\end{array}$ & 10 & 5 & 15 \\
\hline 6 & Dukun kampung & & 1 & 1 \\
\hline & Jumlah & 253 & 267 & 520 \\
\hline
\end{tabular}

Sumber: Profil Desa Simpang Bangkuang

Berdasarkan hasil penelitian di Desa Simpang Bangkuang jumlah anggaran dan realisasi dana Desa yang dapat di ketahui (1) Pendapatan Desa Rp .904.975.828 (2) Alokasi Dana Desa Rp 285.563.571 (3) Dana Desa Rp 595.688.000 (4) DBH Pajak/ Retribusi Rp 12.224.257 (5) PADes Rp 11.500.000. selanjutnya belanja desa (1) Bidang Penyelenggaraan Pemerintah Desa Rp 176.243.029 (2) Bidang Pembangunan Rp 628.884.186 (3) Bidang Pembinaan Kemasyarakatan Rp 12.886.757 (4) Bidang pemberdayaan Masyarakat Rp 130.237.600 (5) Bidang Tak Terduga Rp 3.667.277. Sehingga total belanja desa selama tahun 2016 yaitu Rp.951.918.849.

Tabel APBDes Simpang Bangkuang

\begin{tabular}{|l|l|}
\hline 1. Pendapatan Desa & Rp. 904.975.828 \\
\hline a. ADD & Rp. 285.563.571 \\
\hline b. DD & Rp. 595.688.000 \\
\hline c. DBH Pajak/ Retribusi & Rp. 12.224.257 \\
\hline d. PADes & Rp. 11.500.000 \\
\hline 2. Belanja Desa & \\
\hline a. Bidang Penyelenggaraan Pemerintah & Rp. 176.243.029 \\
\hline b. Bidang Pembangunan & Rp. 628.884.186 \\
\hline c. Bidang Pembinaan Kemasyarakatan & Rp. 12.886.757 \\
\hline d. Bidang pemberdayaan Masyarakat & Rp. 130.237.600 \\
\hline e. Bidang Tak Terduga & Rp. 3.667.277 \\
\hline Jumlah Belanja & Rp. 951.918.849 \\
\hline Surplus/ Defisit & Rp. 55.500.000 \\
\hline 3. Pembiayaan Desa & \\
\hline a. Penerimaan Pembiayaan & Rp. 8.556.980 \\
\hline b. Pengeluaran Pembiayaan & Rp. 8.556.980 \\
\hline c. Selisih Pembiayaan (a-b) & Rp 0 \\
\hline Suber : RJMDes 2016 & \\
\hline
\end{tabular}

Sumber : RPJMDes 2016

\section{Transparansi Pengelolaan ADD Dalam Pembangunan Desa}

Transparansi adalah keterbukaan pemerintah desa dalam memberikan informasi terkait dengan aktifitas pengelolaan sumber daya publik kepada pihak yang membutuhkan yaitu masyarakat dengan tujuan transparan dalam 
penyelengaaran pemerintah Desa Simpang Bangkuang sebagai salah satu wujud pertanggung jawaban pemerintah kepada masyarakat, upaya peningkatan manajemen pengelolaan pemerintah, dan sebagai upaya peningkatan manajemen pengelolaan maupun penyelenggaraan pemerintah yang baik.

Dalam Peraturan Bupati Barito Timur dijelaskan bahwa Alokasi Dana Desa berasal dari APBD kabupaten Barito timur yang bersumber dari bagian dana perimbangan keuangan pusat dan daerah yang diterima oleh kabupaten Bartim untuk desa paling sedikit $10 \%$ (sepuluh persen) setelah dikurangi belanja pegawai. Perolehan ADD masing-masing desa sudah sesuai dengan formulasi penerimaan. Penerimaan ADD bagi setiap desa diharapkan mampu memberikan dorongan terhadap pelaksanaan otonomi desa, sehingga akan berdampak positif pada kemandirian desa.

\section{Pengumuman kebijakan anggaran}

Pengumuman kebijakan anggaran adalah alat ukur dalam keterbukaan pemerintah desa yang harus diketahui oleh publik yaitu masyarakat desa yang sebagai bentuk pertanggung jawaban pemerintah terkait pengelolaan alokasi dana desa (ADD).

Terkait dengan Pengumuman Kebijakan Anggaran di Desa Simpang Bangkuang bapak Edianto selaku Kepala Desa mengatakan. Dalam hal ketersediaan pengumuman dan kebijakan anggaran di Desa Simpang Bangkuang,biasanya kami sampaikan pengumuman melalui kegiatan musyawarah dengan melibatkan masyarakat desa dan pengumuman yang dilakukan secara fisik melalui papan informasi. Kegiatan Desa dalam pembangunan desa terkait penggunaan anggaran bersifat terbuka pada publik baik dalam proses perancanaan, pelaksanaan, dan pertanggujawaban pemerintah desa .

Dwiyanto (2007) mengatakan transparansi dibangun atas dasar arus informasi yang bebas, seluruh proses pemerintahan, lembaga-lambaga dan informasi perlu diakses oleh pihak-pihak yang berkepentingan, dan informasi yang tersedia harus memadai agar dapat dimengerti dan dipantau.

a. Informasi Secara langsung

Informasi secara langsung adalah informasi yang disampaikan secara langsung oleh pemerintah desa kepada masyarakat dalam bentuk musyarawah desa, jadi informasi yang terkait pengelolaan Alokasi Dana Desa disampaikan pada saat musrenbangdes.

b. Informasi Secara fisik

Informasi secara fisik adalah informasi yang disampaikan oleh pemerintah desa melalui media yaitu papan pengumuman, baloho dan spanduk terkait pelaksanaan Alokasi Dana Desa, informasi dapat di lihat di kantor desa maupun di lokasi proyek pembangunan desa. 


\section{Dokumen anggaran yang mudah diakses}

Dokumen anggaran yang mudah diakses adalah salah satu bentuk pertanggangjawaban pemerintah kepada masyarakat terkait pengelolaan anggaran, dengan artian memberikan kebebasan kepada masyarakat desa dalam mengakses dukemen pemerintah desa.

Bapak Tekman Selaku Sekretaris Desa Simpang Bangkuang terkait dengan akses dokumen mengatakan Berkaitan dengan dukumen anggaran yang mudah diakses dengan tindakan membebaskan masyarakat untuk mengakses dukomen anggaran ke kantor desa dan pemerintah desa juga memberikan foto copy dukomendukomen anggaran kepada Badan Permusyawaratan Desa, Lembaga pemberdayaan Masyarakat Desa dan Ketua RT sehingga terakomodirnya keingintauan masyarakat terhadap dukomen anggaran dan memudahkan masyarakat dala mengakses dukumen anggran tersebut.

\section{Laporan pertanggungjawaban Anggaran}

Pertanggungjawaban yang tepat waktu terkait penggunaan anggran adalah salah satu bentuk Pertanggungjawaban pemerintah desa terhadap penggunaan anggaran desa tahap pertama, yang dimana untuk syarat pencairan dana termin kedua oleh desa adalah minimal 50\% dana termin pertama sudah direalisasikan penggunaannya, dibuktikan dengan laporan realisasi penggunaan anggaran dari pemerintah desa. Bapak Edianto selaku Kepala Desa Simpang Bangkuang terkaitan dengan laporan pertanggungjawaban mengatakan: Berkaitan dengan laporan pertanggungjawaban yang tepat waktu, kami selaku pemerintah desa Simpang Bangkuang dalam mempertanggung jawabkan APBDes yaitu melalui sistem pelaporan priodik, setidaknya paling lambat bulan juli tahun berjalan untuk tahap pertama dan akhir bulan januari tahun berikutnya untuk tahap dua. Pembuatannya selalu disertai dengan laporan pertanggung jawaban pemerintah desa yang diajukan kepada pihak kecamatan untuk disampaikan kepada pemerintah kabupaten Barito Timur dan di informasikan juga kepada masyarakat desa Simpang Bangkuang atas hasil implementasi APBDes.

\section{Terakomodasi suara atau usulan rakyat}

Terakomodasinya suara atau usulan rakyat merupakan tahapan musyawarah dimana dilaksnakannya musrenbangdes oleh pemerintah desa yang memberikan kesempatan kepada masyarakat untuk menyuarakan aspirasi yang membangun terkait pengelolaan anggaran desa.

Pendapat Bapak Suriadi selaku Anggota BPD terkait terakomodasinya suara atau usulan rakyat mengatakan: Pemerintah desa Simpang Bangkuang menggunakan sistem skala prioritas artinya kebutuhan masyarakat yang lebih penting dan umum terlebih dahulu direalisasikan dengan mekanisme penentuan penggunaan dana yang telah dibahas dalam masrenbangdes dan dituangkan kedalam APBDes. 


\section{PENUTUP}

\section{Kesimpulan}

Berdasrkan hasil penelitian dan pembahasan pada bab sebelumnya, maka pada peneliti menarik kesimpulan bahwa Transparansi Pengelolaan Alokasi Dana Desa (ADD) Dalam Pembangunan Desa di Desa Simpang Bangkuang Kecamatan Paku Kabupaten Barito Timur sudah di terapkan secara transparan. Hal itu dapat dilihat dari indikator-indikator sebagai berikut:

1. Pengumuman kebijakan anggaran di Desa Simpang Bangkuang yaitu pengumuman melalui kegiatan musyawarah dengan melibatkan masyarakat desa dan pengumuman yang dilakukan secara fisik melalui papan informasi.

2. Dokumen anggaran di Desa Simpang Bangkuang dan mudah diakses dengan tindakan pemerintah desa Simpang Bangkuang membebaskan masyarakat untuk mengakses dukomen anggaran ke kantor desa dan pemerintah desa juga memberikan foto copy dukomen-dukomen anggaran kepada Badan Permusyawaratan Desa, Lembaga pemberdayaan Masyarakat Desa dan Ketua RT sehingga terakomodirnya keingintauan masyarakat terhadap dukomen anggaran dan memudahkan masyarakat dala mengakses dukumen anggran tersebut.

3. Laporan pertanggungjawaban pemerintah Desa Simpang Bangkuang pemerintah desa Simpang Bangkuang yang tepat waktu dalam mempertanggung jawabkan APBDes yaitu melalui sistem pelaporan priodik, paling lambat juli tahun berjalan untuk tahap pertama dan akhir bulan januari tahun berikutnya untuk tahap dua. Pembuatannya selalu disertai dengan laporan pertanggung jawaban pemerintah desa yang diajukan kepada pihak kecamatan untuk disampaikan kepada pemerintah kabupaten Barito Timur dan di informasikan juga kepada masyarakat desa Simpang Bangkuang atas hasil implementasi APBDes.

4. Mengakomodir suara usulan masyartakat desa yaitu pemerintah desa Simpang Bangkuang menggunakan sistem skala prioritas artinya kebutuhan masyarakat yang lebih penting dan umum terlebih dahulu direalisasikan dengan mekanisme penentuan penggunaan dana yang telah dibahas dalam masrenbangdes dan dituangkan kedalam APBDes. oleh karena itu anggarananggaran yang ada benar-benar dialokasikan sesuai suara atau usulan masyakat desa.

5. Faktor pendukung dan penghambat pengelolaan Alokasi Dana Desa di Desa Simpang Bangkuang yaitu bentuk partisipasi masyarakat cukup tinggi dalam proses perencanaa anggaran desa yang dimana masyarakat berperan aktif dalam mengusulkan suara terkait pengelolaan ADD. Disamping itu juga faktor pendukung dalam pengelolaan ADD yaitu masyarakat menerapkan sistem gotong royong dalam kegiatan pelaksanaan pengelolaan ADD. Selanjutnya faktor penghambat dalam pengelolaan ADD yaitu terlambatnya proses pencairan dana oleh pemeritah kabupaten sehingga terhambatnya kegiatan pelaksanaan terkait pengelolaan ADD. Selain itu faktor penghambat dalam 
pengelolaan ADD adalah Sumber daya manusia dari penduduk desa yang berdampak pada kegiatan pengelolaan ADD pada proses perencanaan ADD pada Desa Simpang Bangkuang menerapkan sistem musyawarah desa. Dalam proses musyawarah desa terlihat bahwa partisipasi masyarakat tinggi, namun bentuk-bentuk ususlan kegiatan masyarakat masih cenderung bersifat pembangunan fisik seperti perbaikan jalan dan lain-lain. Padahal kegiatan tersebut tidak bersifat pemberdayaan pada masyarakat sendiri.

\section{Saran}

Berdasarkan hasil penelitian mengenai Transparansi Pengelolaan Alokasi Dana Desa (ADD) Dalam Pembangunan Desa di Desa Simpang Bangkuang Kecamatan Paku Kabupaten Barito Timur peneliti memberikan saran-saran berdasarkan hasil temuan dilapangan, yaitu:

1. Pemerintah Desa Simpang Bangkuang perlu menambah sarana khusus bagi masyarakat untuk menyampaikan saran dan kritik mereka mengenai kenerja dari pemerintah tersebut, seperti kotak saran disetiap RT (Rukun Tangga) yang letaknya strategis agar memudahkan masyarakat desa dalam menyampaikan kritik dan saran mereka. Kemudian pemerintah desa juga bisa memanfaatkan teknologi sehinggga masyarakat desa dalam menyampaikan kritik dan saran bisa melalui telphone atau sms bahkan website desa.

2. Pemerintah Desa Simpang Bangkuang perlu menyediakan suatu kebijakan yang jelas dan dituangkan dalam peraturan desa tentang cara mendapatkan informasi mengenai peyelenggaraan pemerintah desa, bentuk informasi yang dapat diakses oleh masyarakat, bagaimana cara mendapat informasi, durasi waktu untuk mendapat informasi dan prosedur pengaduan apabila informasi tidak sampai kedapa masyarakat.

3. Pembinaan pengelolaan APBDes merupakan sarana efektif untuk keberhasilan program APBDes. Oleh karena itu pemehaman prinsip partisipatif, transparansi, akuntabilitas harus dilakukan seefektif mungkin kepada aparat pemerintah desa, BPD, lembaga kemasyarakatan desa, tokoh masyarakat dan tokoh agama guna meningkatkan semangat, motivasi, dan kreatifitas masyarakat dalam pembanguna desa.

4. Pemerintah Desa Simpang Bangkuang perlu membangun kembali kepercayaan masyarakat Desa Simpang Bangkuang terhadap pemerintah desa dengan jalan melaksanakan prinsip responsif terhadap kebutuhan/ usulan masyarakat dan mertealisasikan dalam bentuk kegiatan pembangunan lian di desa.

\section{DAFTAR PUSTAKA}

Adisasmita, Rahardjo.2011. Pengelolaan Pendapatan dan Anggaran Daerah. Yogyakarta: Graha Ilmu.

Dunn, William N.2003. Analisis Kebijakan Publik. Yogyakarta: Gajah Mada University Press. 
Dwiyanto, Agustus. 2001. Reformasi Birikrasi Publik di Indonesia. Yogyakarta; Gajah Mada.

Dwiyanto, Agustus. 2005. Mewujudkan Good Governance Melalui Pelayanan public. Yogyakarta: Pustaka Belajar.

Gregorius, Sahdan, 2005. Alokasi Dana Desa Untuk Kesejahteraan Rakyat Desa, Yogyakarta: FPPD.

Harsono, Hanifah. 2002. Implementasi Kebijakan dan Politik. Yogyakarta:Rinheka

Kartasasmita, Ginanjar. 1996. Pembanguna Untuk Rakyat :Memadukan Pertumbuhan dan pemerataan. Jakarta : PT. Pustaka Cidensindo.

Kuncoro, Mudrajat.2004. Otonomi dan Pembangunan Daerah: Reformasi, Perencanaan, Srategi dan Peluang. Penerbit Erlangga: Jakarta.

Mardiasmo. 2006. Perwujudan Transparansi dan akuntabilitas Publik Melalui Akuntansi Sektor Publik: Suatu Sarana Good Governance.

Nurcholis, Hanif. 2011. Pertumbuhan \& Penyelenggaraan Pemerintah Desa. Jakarta: Penerbit Erlangga.

Peraturan Mentri Dalam Negeri Republik Indonesia No. 113 Tahun 2014 tentang Pengelolaan Keuangan Desa.

Peraturan Mentri Dalam Negeri Republik Indonesia No. 37 Tahun 2007 tentang Pengelolaan Keuangan Desa.

Peraturan Mentri Dalam Negeri Republik Indonesia No. 39 Tahun 2015 tentang Kode dan Data Wilayah Administrasi Pemerintahan.

Peraturan Pemerintah No. 39 Tahun 2006 tentang Tata Cara Pengendalian dan Evaluasi Pelaksanaan Rencana Pembangunan.

Peraturan Pemerintah No. 43 Tahun 2014 tentang Peraturan Pelaksanaan UndangUndang Nomor 6 Tahun 2014 Tentang Desa.

Peraturan Pemerintah No.43 Tahun 2014 tentang Pengelolaan Keuangan Desa.

Peraturan Pemerintah Nomor 72 Tahun 2005 Pemerintahan Desa dan Pemerintah Desa

Peraturan Pemerintah Nomor 72 Tahun 2005 tentang Desa

Saragih, Juli Panglima. 2003. Desentralisasi Fiskal dan Keuangan Daerah dalam Otonomi. Cetaka Pertama. Penerbit Ghalia Indonesia: Jakarta. 
Setiawan, Guntur.2004. Implementasi Dalam Birokrasi Pembangunan. Bandung: Remaja Rosdakarya Offset.

Siegian, SP.1983. Administrasi Pembangunan. Jakarta: Gunung agung.

Sogiono, 2014. Memahami Metode Penelitian Kualitatif. Bandung: Alfabeta

Thoa, Miftah.2003. Perspentif Perilaku Birokrasi. 2 jilid, Jakarta, PT . Raja Grafindo Persada.

Undang- Undang No 14 Tahun 2008 tentang Keterbukaan Publik

Undang- Undang No 6 Tahun 2014 tentang Desa

United Nations Development Program (UNDP). 1997. Dokumen Kebijakan “Governance For Sustaninable Human Development".Jakarta. 